\title{
Macro and micro determinants of project performance
}

\author{
Authors: \\ Yemesrach Assefa ${ }^{1}$ \\ Oscar P. Rivera ${ }^{1}$ \\ Désiré Vencatachellum ${ }^{1}$ \\ Affiliations: \\ ${ }^{1}$ African Development Bank, \\ Tunisia \\ Correspondence to: \\ Yemesrach Workie \\ Email: \\ ayemesrach@gmail.com \\ Postal address: \\ PO Box 553, Banjul, the \\ Gambia \\ Dates: \\ Received: 25 May 2014 \\ Accepted: 26 Aug. 2014 \\ Published: 18 Dec. 2014 \\ How to cite this article \\ Assefa, Y., Rivera, O.P. \\ $\&$ Vencatachellum, D., \\ 2013, 'Macro and micro \\ determinants of project \\ performance', African \\ Evaluation Journal 2(1), Art. \\ \#86, 9 pages. http://dx.doi. \\ org/10.4102/aej.v2i1.86

\section{Note:} \\ The paper was presented at \\ the 7th African Evaluation \\ Association (AfrEA) \\ conference held in Yaounde, \\ Cameroon, 1-5 March 2014
}

\section{Copyright:}

(C) 2014. The Authors.

Licensee: AOSIS

OpenJournals. This work is licensed under the Creative Commons Attribution

License.
One year from the target date of the achievement of the Millennium Development Goals (MDGs), the result in Africa is only a work in progress. Africa has made progress towards some of the MDGs but needs to draw lessons and improve performance post 2015. This study investigates the development effectiveness of the African Development Bank Group-financed projects using 229 concluded projects between 2004 and 2012 to assess the major determinants of project performance. The study finds that the Bank Group has on average a high level of development effectiveness. Using econometric analysis the study found that country-level variables' interactions with project-level variables explain a substantial share of the variations in project performance. In particular, it affirmed that country policies and institutions and country capacity in general is positively correlated with project performance whilst parallel project implementation units were not correlated. At the micro level, the age of a project, the quality of project design and the choice of programing instrument were also important determinants of project success. The findings of this study therefore will inform the policy formulation processes in the post 2015 agenda.

Un an avant la date ciblée de réalisation des Objectifs du Millénaire pour le développement (OMD), le résultat en Afrique n'est encore qu'un travail en cours. L'Afrique a fait des progrès en faveur de certains des OMD, mais doit tirer des leçons et améliorer les résultats post-2015. Cette étude examine l'efficacité du développement des projets financés par le Groupe de la Banque africaine de développement en utilisant 229 projets achevés entre 2004 et 2012 pour évaluer les principaux déterminants des résultats de projet. L'étude constate que le Groupe de la Banque a, en moyenne, un niveau élevé d'efficacité de développement. En utilisant une analyse économétrique, l'étude a révélé que les interactions des variables au niveau national avec des variables au niveau du projet expliquent une part importante des variations des résultats du projet. En particulier, il a affirmé que les politiques nationales, les institutions et la capacité des pays en général sont positivement corrélées avec les résultats du projet, alors que des unités de mise en œuvre de projets parallèles n'étaient pas corrélées. Au niveau micro, l'âge d'un projet, la qualité de la conception du projet et le choix de l'instrument de programmation étaient également d'importants facteurs de réussite du projet. Les résultats de cette étude informeront donc les processus de formulation de l'ordre du jour post-2015.

\section{Introduction}

Africa continues to register unprecedented economic growth. Africa grew by about $4 \%$ on average in 2013, compared to 3\% for the global economy. ${ }^{1}$ Growth, however, has been marked by wide variations across regions and income groups. The economic growth in Africa is gradually translating into improved social well-being, as shown in the progress made towards the achievement of the Millennium Development Goals (MDGs). With less than a year to the target date of their achievement, the progress Africa made can only be rated as a work in progress. Three out of the eight MDGs targets are on track ${ }^{2}$ to be achieved by Africa in 2015. Africa has sustained progress towards universal primary education, gender equality and empowerment of women and lower HIV and/or AIDS prevalence amongst 15-24 year olds. The challenge for Africa is ensuring that the gains from growth leverage progress on equitable and inclusive development in the post MDGs period. Sustaining Africa's momentum, however, entails adequate, reliable financing and collective learning as a development community on what works and application of the lessons learned in developing and implementing projects and programmes.

Official development assistance (ODA) has been a source of development finance in many African countries. The international community has made efforts to improve the delivery

1.African Economic Outlook 2013

2.Goals 2, 3 and 7 are on track to be achieved by the end of 2015 according to the UN report (United Nations 2013). 
and quality of ODA to countries through galvanising support using frameworks such as the Paris Declaration of Aid Effectiveness and the Accra Agenda for Action. The 2011 survey on monitoring the implementation of the Paris Declaration showed slow progress in development cooperation, in particular in increasing assistance to African countries, the predictability of aid, the alignment of aid with country priorities and the achievement of results. This prompted several changes including a paradigm shift in development cooperation from 'aid effectiveness' to 'development effectiveness', as documented in the Bussan partnership for effective development cooperation in 2011. The Bussan partnership has not only reiterated the principles and established commitments by the Paris Declaration and the Accra Agenda for Action, but it has also specifically outlined concrete actions for implementation. The agreed principles at Bussan to advance common goals by 150 countries and over 50 development organisations are (1) ownership of development priorities by developing counties, (2) focus on results, (3) partnerships for development and (4) transparency and shared responsibility.

Following the Bussan agreement, aid flows to countries showed an increase in 2013. Donors provided a total of $\$ 134.8$ billion in net ODA in 2013. This is a $6.1 \%$ increase in real terms in 2013 from $\$ 125.9$ billion in 2012, amidst the global economic crisis. In spite of this progress, ODA levels continued to be below the internationally agreed target of $0.7 \%$ ODA to gross national income (GNI) ratio. For instance, Development Assistance Committee countries provision of net ODA represents $0.29 \%$ of their combined GNI in 2012. Consistent with the global trend observed, the net ODA received by Africa as a share of per capita declined from $\$ 49.1$ in 2011 to $\$ 47.5$ in 2012. ${ }^{3}$ The share of ODA to Africa is expected to continue to decline in the near future. This trend calls for a critical assessment of development financing in Africa and of the use of development aid. Notwithstanding the declining trend, development aid remains critical for financing development, notably in African countries that are still facing budget constraints and lack of capacity to develop and implement development projects.

It is with this spirit that the African Development Bank Group (AfDB) undertook this study to identify key lessons from its projects, which were the main vehicles used to deliver development aid. The study focused on 229 AfDBfinanced projects concluded between 2004 and 2012 and their contribution to development effectiveness as measured by the achievement of development outcomes. ${ }^{4}$ The article attempts to answer some of the pertinent questions in development policymaking including: what is the extent of development effectiveness of projects financed by the AfDB? What are the major success factors for the achievement of

\section{Organisation for Economic Co-operations and Development 2013.}

4.Development effectiveness refers to achievements at the country level in respect of less attributable, longer-term outcomes and impacts at which the agency efforts are ultimately aimed, and to which it contributes, but which are beyond the manageable, controllable interest of that agency alone (source: Operations the manageable, controllable inte
Evaluations Department 2004). development outcomes in these projects? Has success been related to project characteristics or the country context? Has development partners' technical support during project implementation contributed to the success of a project or not?

This article is organised into five sections. Following the introduction, section two provides a review of the key literature on development effectiveness with a particular focus on the impact of development assistance at the micro level. Section three describes the Bank Group's result measurement. Section four provides insights into the data, methodology and the results of the empirical analysis. Section five provides the conclusion and the key recommendations of the research undertaken.

\section{Development effectiveness reviews}

Studies in the past attempted to measure the impact of external assistance on economic growth and development using time series and cross-sectional data. Such studies influenced the decision-making and economic performance of recipient countries (see Burnside \& Dollar 1997; Dollar \& Svensson 2000; Dollar \& Levin 2005). The results from these studies using macro level data at best indicate mixed results by country and over time. As documented by Rajan and Subramanian (2005), results by such studies were prone to different types of bias including sensitivity to estimation methods such that results were not consistent when alternative estimation methods were used in the analysis or if the sample size changed in terms the number of years or number of countries covered in the study.

To respond to the above highlighted limitations of the approaches, some authors have tried to establish the impact of development assistance at the micro level, by way of documenting the performance of projects. Most of these studies seemed to establish positive relationships between aid and project success without trying to aggregate the impact of aid at country-level. However, several of these studies also demonstrated difficulty in reaching consensus on the meaning and measure of project success. Kilby (2000) argues that project performance or success, which is a measure of the project's net contribution to the economy, cannot be fully assessed until all project costs and benefits are fully realised. That requires systematic collection of data after a project is completed. During the implementation and in the immediate completion phase of a project, project performance can only be assessed on the basis of expected results or soundness of the technical aspects of design and delivery, such as happens with formative type assessments. This is why many researchers have resorted to the use of secondary data and reviews by project managers or studies by evaluators.

Deininger, Squire and Basu (1998) undertook a study to determine the impact of analytical work - country-specific economic analysis and advice on the performance of projects. The analysis indicated that analytical studies (economic and sector work) feed into the project design and have a significant positive impact on the quality of World Bank 
loans for example. However, higher levels of resources spent on supervision and preparation were negatively, rather than positively, related to project success. In contrast, Kilby (2000) and Dollar and Levin (2005), using data from World Bankfunded projects, found that early supervision does have a positive impact on the performance of projects.

Mubila, Lufumpa and Kayizzi-Mugerwa (2000) studied the success factors for AfDB-financed projects completed before 1995 using 146 projects and a simple probit modelling technique. The study suggested that a good policy environment, as measured by the rates of economic growth, inflation and the country's level of development, was an important factor for project success. The study also found that project-specific characteristics, such as the size and sectoral classification of projects, were equally important in determining their success.

Limodio (2011) analysed the factors contributing to the success of infrastructure projects financed by the World Bank between 1979 and 2008 using 1912 infrastructure projects. The study used both binary and six-point ratings of the performance of projects. It also included projectspecific control variables such as mean-normalised size of the project and country-wide variables such as GDP per capita, infrastructure index, democratic accountability, government stability and some variables that account for the quality of national administrative institutions, bureaucracy and corruption, ethnic tensions and external conflict. The results of this study showed that the success of infrastructure projects depended mainly on the quality of implementation.

Similarly, Chauvet et al. (2010) explored the effectiveness of post-conflict aid at the project level. The results suggested that the probability of success of World Bank projects increased with the prevalence of peace. Although the results of the sector-level analysis need to be accepted with caution, the authors indicated that projects in the transport and urban development sectors appeared more successful in postconflict environments. In contrast, education projects seemed less successful and therefore need to be closely supervised. The results further suggested that the longer a project takes to implement over and above the planned project time, the smaller the chance of success. In contrast, better preparation and supervision significantly increase the probability of success of World Bank projects.

A recently completed study by Denizer, Kaufmann and Kraay (2011) using data from more than 6000 World Bank projects evaluated macro and micro correlates of project outcomes between 1983 and 2009. It assessed the impact of project characteristics such as project size, sector and age. The study found that country-level 'macro' measures of the quality of policies and institutions are very strongly correlated with project outcomes, confirming the importance of country-level performance for the effective use of aid resources. A striking finding of this study was that the success of individual development projects varied more within countries than it did between countries. In this regard, the study found that measures of project size, the extent of project supervision and evaluation lags explain a large part of within-country variations. It also found that the quality of World Bank project task managers mattered significantly for the outcome of projects. The first basic but not new finding was that targeting aid to countries with better policies and institutions pays off, as rates of project success were significantly higher in countries with good policy, as measured by the Country Policy and Institutional Capacity Assessment (CPIA) ratings.

In sum, the review of the literature seems to concur that analysing the performance of projects and their critical factors for success provided important insights with regard to increasing the effectiveness of development aid. Existing literature further affirms the importance of project-level characteristics (e.g. design, size, age and sector), together with other critical success factors such as country policy and institutional capacities, monitoring efforts and other exogenous factors such as peace. It is also important to note that many of the studies concentrated only on World Bankfinanced projects, which have their own characteristics. Thus, this article brings a new perspective by focusing on projects financed by the AfDB and focused only in Africa.

\section{Measuring results: The case of the African Development Bank Group}

The AfDB Group is made up of three institutions, namely the AfDB (ADB), the African Development Fund (ADF) and the Nigeria Trust Fund (NTF). Currently, it is composed of 54 African countries (regional member countries) and 25 non-African countries (non-regional member countries). The AfDB has expanded its support to 54 regional member countries (RMCs) with the aim to promote the reduction of poverty and contribute to sustainable economic growth.

The AfDB expanded its support in volume on average by more than $20 \%$ from an average of $\$ 2.6$ billion a year in 2003 to $\$ 6.5$ billion a year in 2013 (ADB 2013). The number of operations financed by the AfDB reached 3550 projects with a value of approximately $\$ 90$ billion in 2013.A total of 2519 projects worth $\$ 52$ billion were completed whilst the remaining projects are either under implementation or closed prematurely in consultation with the borrowing countries.

The AfDB developed several strategies to guide its support over time. The current support to RMCs is guided by the ten-year strategy (TYS, AfDB 2013) that was approved in 2013. The strategy has an overarching goal of supporting Africa's bid to economic transformation through the promotion of inclusive growth and transition to green or sustainable growth. In order to achieve the above two objectives the AfDB defined five operational priority sectors, namely (1) infrastructure development, (2) regional integration, (3) private sector development, (4) governance and accountability and (5) skills and technology. The TYS is accompanied by a result management framework with measurable indicators that will be reported annually 
through the Annual Development Effectiveness Report (ADER), which builds from project level.

The AfDB provided much of its support through the financing of projects ${ }^{5}$ whilst the project activities were implemented by the countries. Over time, the AfDB developed a system to monitor development results of its operations. During project implementation, the AfDB documents progress by means of supervision reports whilst at completion, a Project Completion Report ${ }^{6}$ (PCR) is prepared. PCRs are the AfDB's preferred tool to show concrete results to its shareholders and accumulate knowledge for learning. A PCR assesses the degree to which the project achieved its development objective and delivered outputs as set out in the appraisal report. In addition, the tool assesses the performance of both bank and borrower throughout the project life cycle. It provides quantitative data to substantiate the assessments, and identifies key lessons learned in relation to the achievement of outcomes.

The AfDB introduced three formats for PCRs to measure results at project level. The methodology to measure results has continued to evolve over time as reflected in the various formats. ${ }^{7}$ Format one was introduced in 1996 and used until the second format was introduced and Format two was used between 2001and 2012 whilst its guideline was revised in 2008. As of January 2013, Format three is in use. In all formats a rating system was used for measuring performance. It should be noted that although all formats have some key indicators in common, a significant difference exists. Hence, it is difficult to put all PCRs on a pile. It should also be noted that the capacity of staff to prepare PCRs has also increased over time. On the basis of the forgoing, this study uses PCRs completed using Format two. This format made used of four scale grades for measuring results along five criteria: (1) project outcome, (2) bank performance (design and readiness), (3) bank performance (implementation), (4) borrower performance (design and readiness) and (5) borrower performance (implementation). For this study's purpose, the first criterion (project outcome) is taken.

The rating on development outcome (project outcome) is scored on a scale from 1 to 4 (four-point scale). 1 signifies 'Poor', meaning very limited achievement of objectives with extensive shortcomings; whilst 2 is 'Fair', which means partial achievement of result signifying shortcomings. On the other hand, 3 represents 'Good' (when most of the objectives are achieved despite a few shortcomings) and 4 is given to mean 'Very good' if a project has fully achieved the objectives with no shortcomings.

5.A project is a set of activities designed to produce a unique product, service or result over a limited time period. The ADB in some instances provided technical support in addition to financial support to countries.

6.PCRs are prepared for all public sector operations, except in a few cases such as studies and project preparation facilities. Therefore, private sector operations are not subject to PCR submission but subject to an Extended Supervision Report (ESR) in the private sector department of the AfDB.

7.In the evaluation department database of the ADB, 210 PCRs are available in Format one, 283 PCRs in Format two and three PCRs in Format three as at January 2013.

\section{The data}

The unit of analysis for this study is a project financed by the AfDB. As indicated above, the number of projects financed by the AfDB and fully completed was over 2000 as at the time of this study. From these projects there were PCRs for about 496 projects in all the abovementioned three formats. It was decided to take data from PCRs using Format two because (1) the largest number of PCRs followed Format two and (2) their quality of data was considered to be of a higher standards, whilst very few PCRs are presented using Format three. This study selected a sample size of $80 \%$ of projects that followed Format two. The projects covered in this study were implemented and completed between 2004 and 2012.

\section{The sample}

This section presents the descriptive analysis of the data. These projects were implemented by the RMCs whilst the ADB provided financing with some supervisory assistance: project implementation support in the area of monitoring. The sample was well distributed amongst the RMCs as 42 African countries are covered in the study. ${ }^{8}$ The number of multinational projects in the sample was 29 whilst the remaining 200 projects supported only one country. Close to $90.4 \%$ of these projects were investments projects whilst program-based operations (PBOs) or policy-based operations, a type of projects that support nationally owned policy and institutional reforms in RMCs, accounted for $8.7 \%$ of the sample and technical assistance (TA) operations that provided technical expertise were only $0.9 \%$ of the sample. Furthermore, close to $59.8 \%$ of the projects in the sample were less than $\$ 30$ million in terms of their size. Medium-size operations, for an amount between $\$ 30$ and $\$ 77.5$ million, accounted for about $23 \%$ and projects over $\$ 77.5$ million were about $17.2 \%$ of the sample. In terms of implementation arrangements, $67 \%$ of projects benefitted from the presence of some form of project facilitation unit, such as project management units or parallel structures created for the dayto-day management of the project implementation.

Table 1 provides insight into the performance of projects as assessed by their task managers.

From the 229 projects included in the sample, 8\% had 'Very good' rating in terms of achieving their development objectives, whilst 59\% were rated as 'Good'. Close to $30 \%$ of the projects in the sample were rated 'Fair' by task managers of the ADB and the proportion of projects with a rating of 'Poor' was only $3 \%$.

It is important to note that projects rated 'Very good' were on average large projects with relatively fast first disbursements. In addition, they were implemented in a relatively shorter

8.These countries include: Benin, Burkina Faso, Burundi, Cameroon, Cape Verde, Central African Republic, Chad, Democratic Republic of the Congo, Comoros, Republic of the Congo, Côte d'Ivoire, Djibouti, Egypt, Arab Republic of Eritrea, Ethiopia, Gambia, Ghana, Guinea, Guinea-Bissau, Kenya, Lesotho, Liberia, Madagascar, Malawi, Mali, Mauritania, Mauritius, Morocco, Mozambique, Niger, Madagascar, Malawi, Mali, Mauritania, Mauritius, Morocco, Mozambique, Niger,
Nigeria, Rwanda, Senegal, Seychelles, Sierra Leone, Swaziland, Tanzania, Togo, Tunisia, Uganda and Zambia. 
TABLE 1: Summary of performance of project outcomes.

\begin{tabular}{|c|c|c|c|c|c|c|}
\hline Project classification & Number of PCRs & Percentage & Average historical rating & $\begin{array}{c}\text { Average cost } \\
\text { (millions of UA } \dagger \text { ) }\end{array}$ & $\begin{array}{l}\text { Time for first disbursement } \\
\text { (days) }\end{array}$ & $\begin{array}{c}\text { Effective project age } \\
\text { (years) }\end{array}$ \\
\hline 1. Poor & 7 & 3 & 2.0 & 45.9 & 463 & 8.6 \\
\hline 2. Fair & 68 & 30 & 2.0 & 24.5 & 514 & 8.8 \\
\hline 3. Good & 135 & 59 & 2.3 & 52.1 & 357 & 6.7 \\
\hline 4. Very good & 19 & 8 & 2.4 & 131.0 & 233 & 4.0 \\
\hline Total & 229 & 100 & - & - & - & - \\
\hline
\end{tabular}

Effective project age is calculated by taking the time it takes for projects to come to closure from approval. This is arrived at by counting the number of days from board approval to final actual date of closure in the system.

$\dagger$, The currency used in the AfDB is unit of account $(U A)$ is $\$ 1.55$. Its rate is determined based on the weighted average of a basket of currencies.

TABLE 2: Summary of project performance by sector.

\begin{tabular}{|c|c|c|c|c|c|c|c|c|}
\hline \multirow[t]{2}{*}{ Sector } & \multirow{2}{*}{$\begin{array}{l}\text { Projects projects } \\
\text { by sector }(\%)\end{array}$} & \multirow{2}{*}{$\begin{array}{c}\text { Average cost } \\
\text { (millions of UA) }\end{array}$} & \multirow{2}{*}{$\begin{array}{l}\text { Delay for first } \\
\text { disbursement }\end{array}$} & \multirow{2}{*}{$\begin{array}{c}\text { Project age } \\
\text { (years) }\end{array}$} & \multicolumn{4}{|c|}{ Project classification - Rating (\%) } \\
\hline & & & & & Poor & Fair & Good & Very good \\
\hline Agriculture & 35 & 29.8 & 452 & 8.7 & 6 & 25 & 63 & 5 \\
\hline Power & 3.5 & 78.7 & 305 & 6.7 & 0 & 13 & 88 & 0 \\
\hline Transport & 7 & 62.9 & 370 & 7.4 & 0 & 19 & 69 & 13 \\
\hline Water and sanitation & 6.6 & 65.3 & 565 & 7.1 & 0 & 13 & 67 & 20 \\
\hline Social & 22 & 25.2 & 550 & 8.6 & 0 & 48 & 50 & 2 \\
\hline Environment & 0.4 & 23.3 & $\mathrm{~N} / \mathrm{A}$ & 7.2 & 0 & 0 & 100 & 0 \\
\hline Finance & 1.3 & 112.6 & 195 & 5.7 & 0 & 0 & 67 & 33 \\
\hline Industry and minerals & 0.4 & 26.7 & 188 & 7.2 & 0 & 0 & 100 & 0 \\
\hline Multi-sector & 24 & 87.3 & 166 & 3.9 & 4 & 32 & 50 & 14 \\
\hline
\end{tabular}

period of time than the other projects. In contrast, projects rated 'Poor' or 'Fair' had taken more time (392 days) to receive their first disbursement and their project implementation period exceeded eight years. Furthermore, these projects also received lower ratings during supervision missions undertaken during the project life cycle. In addition, the data showed that $86 \%$ of the 229 projects experienced a complete change of task teams during the implementation, which may have affected the quality of the supervision support. This study will further look at these issues in the econometric analysis.

Table 2 presents project performance in different sectors.

In the sample, a large number of projects financed by the ADB supported the agriculture sector (35\%) followed by multi-sector interventions (24\%) and the social sector $(22 \%)$. The ADB's support in other sectors such as industry, finance and environment was relatively small. Almost all sectors, with the exception of agriculture, social and multi-sector, in $80 \%$ of cases received a 'Fair' rating for the development effectiveness of their projects. Both the agriculture and social sector projects seemed to have a longer implementation period in comparison to other sectors. Projects in the agriculture and social sector did not disburse the loan quickly and took respectively 452 days and 550 days on average.

The above analysis provides important insights into the state of project performance and factors that seem to contribute positively or negatively to the performance of the projects. The next section of the article will take the analysis further using econometric analysis based on the same sample.

\section{Empirical analysis and main findings}

This section presents the data, estimation method, and the main findings of the econometric analysis.

\section{Model specification}

In order to maximise the use of the data points a set of independent variables were introduced progressively into the analysis. The dependent variable is the overall project outcome rating that will be referred to in this study as the performance of a project. The overall project outcome rating is not a continuous variable. It takes a value ranging from one to four as indicated in Section 3. In this study a binary form of this variable was constructed: all projects with outcome ratings of 3 or 4 are coded as 'satisfactory' with a value of 1 , and those with a rating of 1 or 2 are coded as 'not satisfactory' with a value of 0 .

With regard to the independent variables, a set of critical success factors both at country and project levels were introduced progressively. Two models were specified. The first model included basic country and project level variables. The country variables were mainly macroeconomic indicators including: inflation rate (INF), growth rate of real gross domestic product (real GDP), population (POP) and CPIA ratings. For all the macro variables the average during the lifetime of a project was computed. Inflation was entered as a proxy for macroeconomic stability whilst real growth of GDP was inserted in the model to measure the size of an economy. Population size and CPIA were included in the model to measure the complexity of a country ${ }^{9}$ and captured the strength of the country policy and institutions, respectively. CPIA is produced for all countries in Africa by the World Bank and the AfDB. In this study, the data generated by the AfDB was used. In relation to project level variables, project size, the age of a project, the number of co-financiers and dummy variables to measure the impact of a programming instrument at design stage and the impact of war were included. The

9.The CPIA index covers a wider range of policy and institutional issues, namely: (1) economic management, (2) structural policies, (3) policies for social inclusion and equity and (4) public sector management and institutions. 
abovementioned country and project level variables formed the first model. The second model took the first specification and added variables that could measure the support from the AfDB to improve project performance, as measured by the supervision support and the proactive use of portfolio management tools. An attempt was also made to introduce a set of variables that could measure the contribution of task teams managing the projects. All continuous variables were entered in the estimations in their logarithmic form.

The models specified above were estimated using three methods, namely linear probability ordinary least square (OLS), logit and probit. The OLS estimation method assumes that the dependent variable is continuous and the error term is normally distributed. Whilst logit and probit regressions assume that the error terms follow logistic and normal distribution, respectively.

\section{Results of the binary model}

The goal of the specified models is to assess the major determinant of project performance. Firstly, the study attempted to test a broad hypothesis as to whether country (macro) level variables matter most compared to projectspecific factors. The results of the estimations are given at the end the article. The results implied that the model constituted of only country-level variables was insignificant in explaining the change in project performance, although CPIA had a positive and significant coefficient, whilst the model with only project characteristics variables significantly explained the changes in project performance, with age and size of a project being the significant variables. The combined effect of country and project level variables, however, explained more the variation in project performance, which was also closer to the reality on the ground. This finding is consistent with the findings of Denizer et al. (2011).

Five variables were significant determinants of project performance regardless of the method of estimation. These are CPIA, inflation, the age of the project, the dummy for programing instrument and the size of a project. The result in relation to CPIA is consistent with the findings of Dollar and Levin (2005), Denizer et al. (2011) and Mubila et al. (2000). In connection to furthering our understanding of the issue of country capacity and ownership, we replaced CPIA with the rating of the borrower that is generated from the PCRs for each project. Again, a strongly positive relationship between borrower rating and project performance emerged. ${ }^{10}$ The results also indicate that real GDP has a positive but insignificant coefficient. This means that the performance of projects is not associated with the size of the economy. This may look counter-intuitive as generally richer countries tend to have a higher level of capacity to execute projects than poor countries. However, it may reflect the perception of the task managers who rate projects in the poor countries more favorably due to the visible changes in development outcomes. The negative and significant relationship between inflation rate and project performance showed the imminent cost of macroeconomic instability on project performance.

In relation to project characteristics variables, the study discovered a very strong negative relationship between the age of a project and project performance. The age of a project was a significant factor in determining project performance for all estimation. However, the age of a project carries the net effect of complex implementation-related factors. Thus, the underlying causes of extended project implementation should be studied. The coefficient for project size was positive and significant. The project facilitation unit that was introduced to measure the effectiveness of the AfDB effort to augment governments' capacity had negative but insignificant coefficient.

The dummy to measure the impact of the programming instrument had become significant with a negative coefficient for PBOs. In the case of PBOs, which were commonly known as budget support, success rate was lower than that of investment operations. Thus, it shows that project design affected project performance both in terms of the choice of a programming instrument as well as the size of a project. Surprisingly, all variables to measure the quality of the project managing team, its number and composition, have a positive but insignificant coefficient.

Building on the first model, all variables related to the project management team were dropped and new variables to measure AfDB support were introduced. In order to measure the effectiveness of the AfDB's support, two variables were introduced. The first one was the rating of supervision missions during the project life cycle to see if projects at completion achieved higher or lower rates on average. Secondly, internally generated portfolio management flags were introduced to see if a project was problematic or potentially problematic based on certain indicators and whether that triggered any action to improve performance. A dummy was introduced with a value of one for projects that had not been flagged as problematic or potentially problematic and a value of zero if the project had been flagged in one of the two portfolio indicators. The result indicated that there was positive and significant coefficient for the above two variables. The finding of this study was that lower average supervision rating during the lifetime of a project was related to low performance at the end of a project, indicating the inability of supervision efforts to turn less successful projects around. Similarly, a positive relationship emerged between a project that was not flagged as problematic or potentially problematic and strong project performance. Lastly, regardless of the supervision efforts, projects with implementation problems tend to perform badly.

The dummies to capture the specific nature of fragile countries were not significant. ${ }^{11}$ In order to further confirm this finding, we introduced a dummy variable for war to measure the impact of conflict and political instability on 
project performance. The dummy takes the value of one if there was a war during the project implementation period and a zero otherwise. The result shows that war entered the model with a negative but insignificant coefficient. This finding is similar to that of Kilby (2012).

\section{Conclusion and recommendations}

Most of the African countries, in particular in sub-Saharan Africa, are at a crossroads. They achieved a great deal of social and economic development results over the past decade. The lessons from the past could have a huge impact in informing future policies and programmes. Projects seem to be the major vehicle to deliver development; hence, it is critical to understand their success factors. The findings of this study contribute to an improved understanding of success factors for project performance. The key finding of the study is that project characteristics are the major determinants of project performance, whilst macro level variables also contribute to project performance although to a lesser degree. However, some macroeconomic policy variables were consistently related to project performance, such as CPIA. Hence, countries could improve on development effectiveness by reforming their economies in ways aimed at improving their CPIA ratings and maintaining macroeconomic stability whilst improving project performance through enhancing their project implementation capacities. The AfDB could make efforts to further improve on project design, the selection of programming instruments and pay attention to the complexity of countries.

Finally, although the econometric analysis provided important insights about the determinants of project performance, there remains a significant level of variation in project performance that is not explained with the above models. The models specified thus far only explain at most around $30 \%$ of the differences in project performance as shown in the respective adjusted $R$-squared values. This means that much remains unknown in terms of explaining variance in project performance. Further research should be encouraged to gain further insights in this area.

The following are the main recommendations:

- Improving a country's CPIA ratings through policy dialogue with RMCs is critical for the success of a project. The policy dialogue should be informed by highquality empirical studies that can ultimately improve the country's policies and institutional capacities.

- Strengthening project implementation capacity at the country-level could contribute substantially to improved project performance through enhancing smooth implementation of projects as per the project plan.

- Improving project design through not only focusing on technical feasibility but also considering the choice of programming instrument and the scale of the intervention.

- The AfDB should strengthen its supervision and portfolio management tools to achieve greater impact in project performance.

\section{Acknowledgements}

The views expressed in this paper are only the views of the authors and do not represent the view of the African Development Bank Group. We would like to acknowledge the contributions from Houssem Eddine during the econometric analysis and in supervising the data entry. We would like to thank Cherifa Dimassi and Jihen Dridi for their dedicated effort in collecting data. We also like to thank Rodrigo Salvado Cesar for his support at the initial stages of the study.

\section{Competing interests}

The authors declare that they have no financial or personal relationship(s) that may have inappropriately influenced them in writing this article.

\section{Authors' contributions}

Y.A. (African Development Bank), O.P.R. (African Development Bank) and D.V. (African Development Bank) equally contributed to the research and writing of this article.

\section{References}

African Development Bank, 2013, Annual report, The African Development Bank Group, Tunis, Tunisia.

African Development Bank Group, 2013, Ten year strategy of the African Development Bank Group, AfDB, Tunis, Tunisia.

Burnside, C. \& Dollar, D., 1997, 'Aid, policies, and growth', policy research working paper 1777, Development Research Group, The World Bank, Washington, DC.

Chauvet, L., Collier, P. \& Duponchel, M., 2010, 'What explains aid project success in post-conflict situations?', policy research working paper 5418, The World Bank, Washington, DC.

Deininger, K., Squire, L. \& Basu, S., 1998, 'Does economic analysis improve the quality of foreign assistance?'. World Bank Economic Review 12(3), 385-418. http:// dx.doi.org/10.1093/wber/12.3.385

Denizer, C., Kaufmann, D. \& Kraay, A., 2011, Good countries or good projects? Macro and micro correlates of World Bank project performance, n.p.

Dollar, D. \& Levin, V., 2005, 'Sowing and reaping: Institutional quality and project outcomes in developing countries', policy research working paper series 3524 , The World Bank, Washington, DC.

Dollar, D. \& Svensson, J., 2000, 'What explains the success or failure of structural adjustment programmes?', Economic Journal 110(466), 894-917. http://dx.doi. org/10.1111/1468-0297.00569

Kilby, C., 2000, 'Supervision and performance: The case of World Bank projects', Journal of Development Economics 62(1), 233-259. http://dx.doi.org/10.1016/ S0304-3878(00)00082-1

Kilby, C., 2012, 'Assessing the contribution of donor agencies to aid effectiveness: The impact of World Bank preparation on project outcomes', working paper \#20, Villanova School of Business Economics, Villanova, PA.

Limodio, N., 2011, The success of infrastructure projects in low-income countries and the role of selectivity, n.p.

Mubila, M., Lufumpa C. \& Kayizzi-Mugerwa, S., 2000, 'A statistical analysis of determinants of project success: Examples from the African Development Bank', research paper \#56, The Africa Development Group, Tunis, Tunisia.

Organisation for Economic Co-operation and Development, 2013, 'Ending poverty highlights', development co-operation report, OECD, Paris, France.

Operations Evaluations Department, 2004, 'Annual review of development effectiveness report', approach paper, African Development Bank, Tunis, Tunisia.

Rajan, R.G. \& Subramanian, A., 2005, 'Aid and growth: What does the cross-country evidence really show?', working paper WP/05/127, International Monetary Fund, Washington, DC.

United Nations, 2013, 'Trends and progress in international development cooperation', report of the Secretary-General Economic and Social Council E/2012/78, UN, New York, NY. 
ANNEXURE 1a: Result of the good country or good project hypothesis.

\begin{tabular}{|c|c|c|c|c|c|c|c|c|c|}
\hline \multirow[t]{2}{*}{ Variable type } & \multicolumn{3}{|c|}{ Linear probability model } & \multicolumn{3}{|c|}{ Logit model } & \multicolumn{3}{|c|}{ Probit model } \\
\hline & Coefficient & $t$ & $P>t$ & Coefficient & $Z$ & $P>z$ & Coefficient & $z$ & $P>z$ \\
\hline \multicolumn{10}{|l|}{ Country characteristics } \\
\hline LINF & 0.0169 & -0.5 & 0.619 & -0.0729 & -0.5 & 0.616 & -0.044 & -0.49 & 0.909 \\
\hline LRGDP & 0.0104 & 0.12 & 0.905 & -0.038 & 0.3717 & 0.918 & 0.026 & 0.11 & 0.623 \\
\hline LPOP & 0.011 & 0.23 & 0.818 & 0.051 & 0.23 & 0.816 & 0.031 & 0.23 & 0.817 \\
\hline CPIA & 0.175 & 1.71 & 0.09 & 0.7499 & 1.71 & 0.089 & 0.465 & 1.72 & 0.086 \\
\hline Constant & 0.3174 & 0.5 & 0.619 & -0.753 & -0.26 & 0.791 & -0.491 & -0.28 & 0.782 \\
\hline Number of observation & 200 & - & - & 200 & - & - & 200 & - & - \\
\hline Prob $>F /$ Prob $>$ chi $^{2}$ & 0.4196 & - & - & 0.4143 & - & - & 0.4095 & - & - \\
\hline Adjusted $R$-squared / Pseudo $R^{2}$ & 0.0004 & - & - & 0.0148 & - & - & 0.015 & - & - \\
\hline
\end{tabular}

ANNEXURE 1b: Result of the good country or good project hypothesis.

\begin{tabular}{|c|c|c|c|c|c|c|c|c|c|}
\hline \multirow[t]{2}{*}{ Variables } & \multicolumn{3}{|c|}{ Linear probability model } & \multicolumn{3}{|c|}{ Logit model } & \multicolumn{3}{|c|}{ Probit model } \\
\hline & Coefficient & $t$ & $P>t$ & Coefficient & $z$ & $P>z$ & Coefficient & $z$ & $P>z$ \\
\hline \multicolumn{10}{|l|}{ Project characteristics } \\
\hline Project size & 0.050 & 2.02 & 0.044 & 0.299 & 2.09 & 0.036 & 0.173 & 2.14 & 0.033 \\
\hline Number of co-financiers & 0.002 & 0.14 & 0.88 & 0.017 & 0.18 & 0.854 & 0.0153 & 0.28 & 0.781 \\
\hline Age of a project & -0.001 & -5.20 & 0.000 & -0.0009 & -4.56 & 0.000 & -0.0005 & -4.74 & 0.000 \\
\hline Dummy for PBO & -0.179 & -1.50 & 0.135 & -1.001 & -1.33 & 0.185 & 1.32 & 3.59 & 0.000 \\
\hline Constant & 0.917 & 8.29 & 0.0000 & 2.184 & 3.48 & 0.001 & - & - & - \\
\hline Number of observation & 200 & - & - & 2000 & - & - & 200 & - & - \\
\hline Prob $>F /$ Prob $>$ chi $^{2}$ & 0.000 & - & - & 0.0000 & - & - & 0.0000 & - & - \\
\hline Adjusted $R$-squared / Pseudo $R^{2}$ & 0.134 & - & - & 0.1298 & - & - & 0.129 & - & - \\
\hline
\end{tabular}

ANNEXURE 2: Binary estimation result for Model 1.

\begin{tabular}{|c|c|c|c|c|c|c|c|c|c|}
\hline \multirow[t]{2}{*}{ Variables } & \multicolumn{3}{|c|}{ Linear probability model } & \multicolumn{3}{|c|}{ Logit model } & \multicolumn{3}{|c|}{ Probitmodel } \\
\hline & Coefficient & $t$ & $P>t$ & Coefficient & $z$ & $P>z$ & Coefficient & $z$ & $P>z$ \\
\hline \multicolumn{10}{|l|}{ Country characteristics } \\
\hline LINF & -0.059 & -1.74 & 0.083 & -0.281 & -1.58 & 0.114 & -0.179 & -1.67 & 0.096 \\
\hline LRGDP & 0.031 & 0.39 & 0.698 & 0.216 & 0.49 & 0.626 & 0.170 & 0.65 & 0.518 \\
\hline LPOP & 0.030 & 0.77 & 0.440 & 0.230 & 0.90 & 0.368 & 0.133 & 0.87 & 0.382 \\
\hline CPIA & 0.160 & 1.72 & 0.086 & 0.906 & 1.80 & 0.070 & 0.533 & 1.79 & 0.074 \\
\hline \multicolumn{10}{|l|}{ Project characteristics } \\
\hline Project size & 0.067 & 2.22 & 0.028 & 0.356 & 2.06 & 0.039 & 0.207 & 2.08 & 0.037 \\
\hline Age of a project & -0.001 & -4.78 & 0.000 & -0.009 & -4.30 & 0.000 & -0.0006 & -4.45 & 0.000 \\
\hline Number of co-financiers & 0.009 & 0.018 & 0.612 & 0.092 & 0.77 & 0.443 & 0.062 & 0.87 & 0.385 \\
\hline Dummy for PBO & -0.228 & -1.80 & 0.073 & -1.28 & -1.55 & 0.122 & -0.772 & -1.64 & 0.101 \\
\hline Constant & 1.448 & 2.15 & 0.033 & 4.11 & 1.16 & 0.246 & 1.345 & 1.72 & 0.08 \\
\hline Number of observations & 199 & - & - & 200 & - & - & 200 & - & - \\
\hline Prob $>F /$ Prob $>$ chi $^{2}$ & 0.000 & - & - & 0.000 & - & - & 0.0000 & - & - \\
\hline
\end{tabular}


ANNEXURE 3: Binary estimation result for Model 2A.

\begin{tabular}{|c|c|c|c|c|c|c|c|c|c|}
\hline \multirow[t]{2}{*}{ Variable type } & \multicolumn{3}{|c|}{ Linear probability model } & \multicolumn{3}{|c|}{ Logit model } & \multicolumn{3}{|c|}{ Probit model } \\
\hline & Coefficient & $t$ & $P>t$ & Coefficient & $z$ & $P>z$ & Coefficient & $z$ & $P>z$ \\
\hline \multicolumn{10}{|l|}{ Country characteristics } \\
\hline LINF & -0.612 & -1.62 & 0.107 & 0.2378 & 0.04 & 0.966 & -0.238 & -1.64 & 0.101 \\
\hline LRGDP & 0.051 & 0.56 & 0.579 & -9.795 & -0.58 & 0.559 & 0.194 & 0.57 & 0.570 \\
\hline LPOP & 0.030 & 0.56 & 0.573 & -0.537 & -1.56 & 0.118 & 0.062 & 0.31 & 0.075 \\
\hline CPIA & 0.142 & 1.28 & 0.201 & 1.7051 & 1.58 & 0.114 & 0.435 & 1.06 & 0.290 \\
\hline \multicolumn{10}{|l|}{ Project characteristics } \\
\hline Project size & 0.041 & 0.58 & 0.562 & 0.187 & 1.4 & 0.161 & 0.187 & 1.4 & 0.610 \\
\hline Project age & -0.0007 & -3.14 & 0.002 & -0.002 & -1.72 & 0.080 & -0.002 & -1.72 & -0.085 \\
\hline Number of co-financiers & 0.0094 & 0.49 & 0.625 & -0.002 & 0.67 & 0.504 & 0.0600 & 0.67 & 0.504 \\
\hline Dummy for PBO & -1.57 & -1.47 & 0.14 & -0.923 & -1.55 & 0.121 & -0.923 & -1.55 & 0.121 \\
\hline \multicolumn{10}{|l|}{ Evaluation characteristics } \\
\hline Supervision rating & 0.271 & 2.38 & 0.018 & 1.864 & 2.06 & 0.039 & 0.918 & 2.16 & 0.031 \\
\hline Constant & 0.59 & 0.78 & 0.439 & 16.1622 & 1.35 & 0.178 & 1.175 & 0.41 & 0.684 \\
\hline Number of observations & 154 & - & - & 154 & - & - & 154 & - & - \\
\hline Prob $>F /$ Prob $>c^{c h i^{2}}$ & 0.000 & - & - & 0.000 & - & - & 0.000 & - & - \\
\hline Adjusted $R$-squared / Pseudo $R^{2}$ & 0.336 & - & - & 0.4 & - & - & 0.288 & - & - \\
\hline
\end{tabular}

ANNEXURE 4: Binary estimation result for Model 2 B.

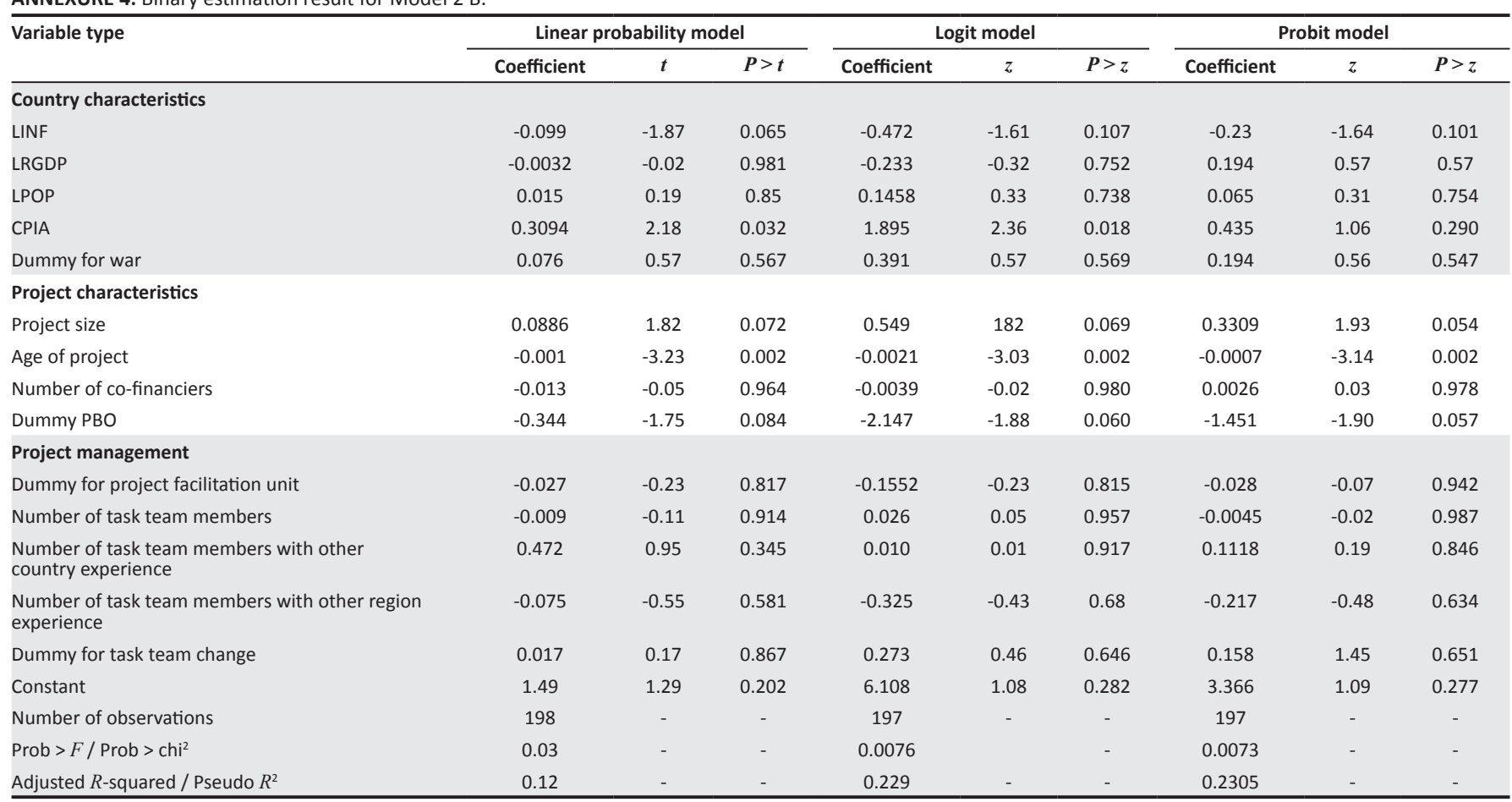

